\title{
Local Wisdom as a Planning Strategy and Sustainable Settlement Development in ToKaili Traditional Settlement, Central Sulawesi, Indonesia
}

\author{
Zaenal Sirajuddin \\ Correspondence: Department of Architecture, Engineering Faculty, Tadulako University Central Celebes. Palu 94118, \\ Indonesia. E-mail: ybmtondo@gmail.com; zaenal@untad.ac.id
}

Received: March 23, 2020 Accepted: April 22, 2020 Online Published: May 28, 2020

doi:10.5539/res.v12n2p107 URL: https://doi.org/10.5539/res.v12n2p107

\begin{abstract}
Indonesia is home to many tribes spread across many islands. It is home to local wisdom that thrives and is preserved in the community. The Kaili tribe (ToKaili) is one of the tribes that live on the island of Sulawesi which is located in the province of Central Sulawesi. This has unique local wisdom because ToKaili is one of the tribes in Indonesia that was formed due to evolutionary development starting from moving to a sedentary lifestyle, to settling which is worthy of study by many researchers in the field of architecture. An interesting part of local wisdom is their customs and traditions in organizing and designing their settlements since ancient times. The ToKaili settlement planning and design process mainly depends on how customary law regulates the phenomena of community life and shapes sustainable planning strategies. The purpose of this study is to reveal the phenomenon of local wisdom To Kaili in planning and designing harmonious sustainable settlements. This study uses phenomenology as a method for analyzing ToKaili local wisdom and finding planning strategies and designing harmonious solutions. It was found that variations or patterns are ranging from micro-scale settlements to large scale settlements that are interrelated and metamorphosed from micro-scale settlements to large scale settlements (From Sou to Ngata bete) Formed by customary rules.
\end{abstract}

Keywords: harmonious settlement, local wisdom, planning strategy, settlement scale, metamorphose, phenomenon performed by to Kaili

\section{Introduction}

Indonesia is the largest archipelago in the world with thousands of small and large islands and is inhabited by one or more tribes. Each tribe has local wisdom that looks similar to each other but is not the same.

Tokaili's uniqueness can be seen from the process of settlement growth which requires a very long time and has never been revealed by researchers before.

This tribe has a relic in the form of a stone statue named Menhir which is inherited from the previous tribe. The existence of stone culture shows the intervention of immigrants who came to the island a year ago with about relatives by carrying out the stone culture which is the ancestral heritage shown by the menhir stones which were found in various places in Central Sulawesi.

The arrival of foreign tribes who migrated from outside the island is predicted to come through the Asian peninsula through two phases: The first phase is through the bay of Bone, down into the Saddang River and ends at the Lore Valley. These migrants came to be known as carriers of stone culture. In the second phase, the migrants come via Minahasa to Bukit Igor until they reach Lore hill and pass through West Sulawesi, migrants in this phase are known as pottery/bearers of pottery culture. When these immigrants arrived in Sulawesi was unknown because there was no detailed information regarding the date when they migrated. (Kudernt.W, 1940, 1944).

Before the arrival of migrants from outside Celebes Island, there was already a group of clever people who had settled in the Center of Celebes. The emergence of migrants has influenced cultural acculturation and shaped many other local pearls of wisdom around it. This migrant appearance classifies the community into two: immigrants and smart people. Their cultural inequality gave birth to a war culture which led to the form of two groups in society namely the ruling group and the workers' group. The ruling group (Madika) and the working or slave community. Pengayuan (Cultural warfare) forms strata or classes in a society characterized by determined wars between existing groups, Who wins the war becomes the ruler and rules as Madika while the losers turn into workers/slaves (Watau) from Madika (Mattulada, 1988).

Community grouping into two consequences on the division of territory, Madika occupies a valley named Balingkae, 
seeded or occupies a hilly area that is around Balingkae. The differences in the area of residence showed the existence of social classes in the To Kaili community at that time. This acculturation not only occurred at a time when migrants from outside the island entered but continued when other migrants came from around Sulawesi such as the Bugis and Mandar tribes from western Sulawesi. the presence of migrants from outside the island of Sulawesi as well as migration from the surrounding area has an impact on changes in tribal warfare (Pengayuan) within the ToKaili community experiencing cultural development and giving birth to an enlightened and wise group of people called Tadulako.

Tadulako's presence in the Tokaili community initiated the cessation of inter-tribal warfare culture and shifted it to a culture of living together that formed community groups that we're able to work together and not fight each other, and the custom of marrying between families between now turned into family marriages outside (From Endogamy to Exogamy).

The presence of an exogamous marriage culture makes the community more advanced and requires suitable and growing settlements. This development directs the form of settlements that develop from micro-scale to large scale settlements accompanied by the presence of customary rules which are local wisdom and continue to develop and become the foundation of the formation of harmonious settlements. Based on this description, the purpose of this study is to reveal the role of customary rules which are a form of local wisdom as a harmonious and sustainable settlement planning and development strategy.

\section{Background Knowledge}

In Indonesia, each tribe has various identical conditions, so it cannot be compared to each group of people with each other as well as various tribes in the world so that the tribes can be grouped based on identical things.

To start this research, a variety of knowledge is needed as background knowledge that helps researchers see various phenomena from each tribe, especially the tribe that is the object of this research. The literature used in this study is not intended a theoretical framework but, as a background of knowledge supporting researchers in carrying out the research process, theories and concepts that are studied as background knowledge include: Theories of vernacular architecture, theories and concepts of settlement, theories and concepts about cultural canalization in society, study studies

The theories and concepts above are intended as researchers' initial knowledge which is used to capture various phenomena in the field by needs from this study.

\subsection{The Concept of Sustainable Pragmatism Planning}

The development of the concept of pragmatism planning has developed very rapidly in the planning dimension, several opinions that reveal the concept of pragmatism, including expressing the influence of US pragmatic philosophy on the development of theory about the nature, purpose, and method of planning. Describes the key contributions of pragmatic and "neo-pragmatic" philosophers and identifies the influence of pragmatism on the initial concept of planning as a rational process; on the perspectives of Friedman, Lindblom, and Schon; on the development of the "critical pragmatism" of Forester; and on the contribution of other planning theories in the 1980s and 1990s. Identify the importance of pragmatic ideas in emphasizing the planning dimension as a practical social learning activity, which must utilize human capacities and promote the ability to transform critical transformative systemic work in the public sphere. (Healey, Patsy, 2009).

The philosophical position of pragmatism in the conceptual scaffolding for design thinking. Contributing to several designs that stem from the concept of pragmatism. Broadly speaking, thinking covers a broader area of how the main concepts of design thinking resonate by applying John Dewey's pragmatic philosophy. The argument presented shows that there is a link between pragmatic perspectives and design thinking. Pragmatism offers a well-developed and coherent articulation of concerns to design pragmatic thoughts and perspectives that can be valuable at theoretical and practical levels. At the theoretical level, it can inform and inspire the development of discourse about design. At a practical level, pragmatic concepts can be operationalized to inform and guide building designs and help understand and manage rational design processes. (Dalsgaard, Peter, 2014), the implementation of the concept of pragmatism and pragmatism thinking can also be applied to the implementation of planning and design strategies based on local wisdom.

Thinking about code coding on the implementation of the concept of pragmatism can obscure the construction of planning and design with a holistic paradigm and can be followed up in efforts to develop the concept of sustainability planning by applying a sustainable development policy and planning approach. The classical dichotomy recognized more than a century ago by pragmatic philosopher William James who stated to think hard and think softly, or for that matter, those who believed in more and better information to overcome the challenges of sustainability and those who relied on the power of policy. The thinking then argues that the sustainable development approach is based on the philosophy of pragmatism as a means of connecting hard and soft perspectives with sustainability planning, policy, and action. After detailing how hard and soft-minded temperaments among proponents of sustainability are translated into various types of understandings and initiatives, a pragmatic framework for holistic sustainability planning and a proposed set of policies. 
This framework is arguably based on an understanding of pragmatic theories about truth and rationality, integration and basic processes for action, and human experience as a test of public values and priority actions. This opinion contributes to the evolution of a culture which refers to pragmatic philosophy. More relationship with the work of environmental philosophy highlights the usefulness of pragmatism in building so that the philosophy of sustainable development is a planner whose members consist of democratic societies and can work towards a shared understanding that the process of communication and ongoing interaction between citizens and experts needs to be maintained to encouraging sustainable development, that knowledge must be generated and tested in public. Context and the story of the concept of pragmatism has stood side by side with scientific models and statistics, important steps towards sustainability can be made in the overall planning profession. (Holden, Meg, 2008)

\subsection{Vernacular Architecture}

Vernacular in local architectural terms, interpreted as architecture without an architect. And in regional languages also interpreted as local languages, which are used to mention local forms that are loaded with local content, including elements of culture, environment, a local climate which are manifested in physical architectural forms such as layout, structure, and detail of ornaments.

Other colloquial terms refer to the local potential of building materials, local labor, and local wisdom. These vernacular terms were originally related to primitive architecture such as in the form of shelter, spatial use, orientation, construction, natural influence and human behavior (Olive, 1997).

The characteristics of vernacular buildings (Olive, 1997) consist of:

- Buildings are not supported by principles and theories,

- Adapt to the environment,

- Following the capabilities of the community (technology and economy),

- Explain community culture,

- Be open to natural resources in the environment and can always accept changes that can last a long time. So that the vernacular generator is a customary regulation that forms the backbone of the local wisdom of a community group.

Vernacular architecture when viewed as a collection of houses and other supporting buildings that are bound by the availability of resources from the environment shows the strategic role of local wisdom in mitigating awareness to be together. Togetherness in forming houses and other supporting elements are formed due to efforts to meet specific needs and accommodate culture that influences the behavior of community groups formed. This vernacular architecture is born of a group of people who live together and form groups (communities), so that communities formed by kinship and homogeneity make traditions as a guide for people to live in groups and are handed down from generation to generation, and are called traditional community assemblies. Communities that make up shared houses, such as architects who also work as workers, make customary rules as living rules that lead people to build groups of houses and are called a village, and are located in the interior, and are more traditional, adaptive, characterized by local customs and their nature. Community groups that are formed tend to settle from generation to generation, thus regard it as a place of birth.

The embodiment of occupancy and all its facilities is more determined on the process rather than the product. people in one community are always based on their carpentry technology and must implement the initiation process at each stage and be aware of the traditions of the community, for example before the commencement of activity celebrations that show the strength of customs ties in their environment. Architecture is not only a tangible form but can be a social space, symbolic space, which reflects the space of creation and its inhabitants. (Olive, 1997).

Implementation of the vernacular building construction process, generally determined from generation to generation or based on agreement and related to local orientation, construction of certain buildings will be the same, although not entirely the same. Local orientation becomes a characteristic of vernacular architecture (vernacular settlement) so that it describes three things, namely: the place where it is located, people who have the same behavior or who adhere to the same customary rules, and a certain period so that local orientation becomes the keyword and where the vernacular is located called local villages because they can grow, assimilate naturally, and continue to grow to this day.

Local villages grow and are born from certain ethnic communities and have certain ethnic traditions so that they are always in line with the cosmology they understand, outlook on life, lifestyle, which has a distinctive appearance as a reflection of identity developed in an innovative, creative, syncretic way and eclectic. Approach, planning, and design are seen as anonymous, indigenous, original, naive, primitive, rude, spontaneous, popular, and local or people's basis. The use of norms, customs, culture, climate, and the potential of local material that has gained recognition is based on the long experience (trial and error) of the community groups that embrace it (Mete Turan, 1990). 


\subsection{Settlement}

Settlement or human settlement is defined as a place of life and a place of contact (interaction) between humans and humans, humans with nature and humans with natural rulers. Settlements filled with humans and the physical container where humans live, and where people gather and live together.

Settlement is the result of joint work to build houses and facilities needed in human life.

Settlements can also be said as a collection of houses inhabited by residents, forming a community as a place to live, work, and a place to communicate. In addition, settlement should not be described only in three dimensions, but must be seen from four dimensions, because the human element of life always changes its character and culture in certain units of time (Doxiadis, 1976).

There are 5 elements of settler formation (human Settlement) according to Doxiadis (1976), the elements are as follows:

Nature as an element, i.e. a place or container of a village formed or shaped by elements of the environment such as geography, topography, soil, water resources, plants, animals and climate or weather. To all these elements interact so that it functions as a village or village.

Humans as elements, i.e. people who live in nature and perform activities, such as: biological activities, sensations, perceptions, emotions, and morals associated with the values and norms held by humans or groups of people.

Community as an element, a group of people living together form a residential environment, such as forming social strata, forming culture (culture), forms the administrative area.

Protection (shell) as an element, i.e. the structure of a container in which there are living and living human beings, such as housing, community services, business centers, recreational containers, commercial containers, offices.

Networks or social capital as elements, i.e. systems that are naturally artificial and functioning as a settlement, such as: Water supply systems for settlers' needs, roads for transportation, drainage channels, communications networks, power grids and all needs Other physical.

The five elements of the settlement are aspects that must be studied holistically to find an ideal settlement (Doxiadis, 1976). Elements of the village are in charge of maintaining a dynamic balance, and expressed differently on each part, every scale and during the process of settlement evolution. The basis of a settlement is an ecological unit that is hierarchically linked to each other of each element. Thus the law of a settlement is not a simple causal law, but a statistical law concerning the effects of change.

Settlement in the residential unit scale to become a city, experiencing synchronic and diachronic changes that develop from one phase to the next. To analyze a settlement, it must connect between the past and the present. Thus the village is a dynamic and changing all the time and requires new innovations to stay alive. The village will die, if it no longer provides services to human needs. The ideal settlement must provide comfort, security, tranquility and safety for people.

Basically, settlements are created by humans to become a space for movement with territorial boundaries based on population, therefore settlements create the physical and institutional environment of a society. The process of change (evolution) that occurs is one factor that extends the life of settlements through a process that continues to develop. The process of evolution can be analyzed by clarifying the size of the object of observation (settlements, housing units, dwellings, residential spaces) both population and area. The quality of the relationship between units or parts of the village with other parts influences the morphogenesis of the settlement, variations in the shape of morphogenesis depend on the availability of physical data and non-physical factors, including social, economic, political, administrative, technological and aesthetic factors, which make the settlement more complex (Doxiadis. 1976).

A settlement is a place of residence in an environment that has a clear boundary or area, a place that consists of an inner environment and an 'outer environment that has a boundary scope of the settlement (Schulz, 1985). While the village is the result of human relations with the environment that functions as the center of human encounters, so it is not only a place of humans, but is part of a larger environment. Thus the village must have elements of "inner environment" and "external environment". Settlement is seen as something unique and interesting because in general it has a tendency to make the elements of the environment become a dominant, interesting because it functions as a magnet that makes people will have an attachment or become an adhesive between them. Village existence has characteristics that are achieved through physical environmental conditions and non-physical conditions such as culture, social life of the community is a system that has been stable and patterned somewhere and is related to the history of the community.

Other opinions about settlements state that settlements are part of a large area within an area, which functions as a group center and is an interpretation of a site, land or plot and is transformed to the place where people live.

Some environments, which have specific natural characteristics and have spatial structures, are referred to as plains, 
valleys and ponds (basins), while spaces are equipped with natural elements, e.g. topography with owned rocks, vegetation and water and equipped with very important orientations such as the relationship between the site with light, weather and natural conditions that are part of the microclimate which is complemented by human life is also a settlement. (Keizer, Majorie.B, 1978).

The growth and development of settlements that continue to occur until they appear in the late 60 s are defined as a guide to housing and human life in developing a particular community. Settlement exists because people begin to recognize and develop culture and coincide with the presence of civilization or human culture. The structure and shape of the house is considered as an embodiment of the cultural values of the people. Houses are used as human shelter in the face of climate change and weather (heat, cold, rain and wind). The house is also called a place of residence because it functions as a place of rest, a place to build a family, a place of work, and a symbol of social status (Rapoport, 1969, 1977).

Human behavior in responding to homes varies and changes depending on the place where it is located. For traditional communities, the house is associated with various aspects, such as social, cultural, religious, and physical aspects. So houses and settlements are basically part of the area where there are residents who live, take part in work activities, try, connect with fellow settlers as a community and meet the various needs of life and activities (Rapoport, 1977).

\subsection{Vernacular Settlement}

The term vernacular settlements in architecture are often defined as settlements formed without architects so that settlements formed are identical to primitive or traditional settlements, settlements that are thus formed by customary rules as architects and are often identified with vernacular. The term vernacular is also defined as the local language, the local language as expressed in the previous discussion which is used to express people's architectural works. Thus, in settlements, the term vernacular settlement is used to refer to local forms that are loaded with local content, such as: Loaded with cultural elements, the environment including the local climate which is manifested in physical architectural forms such as layout, structure, ornamental details, and ornament as explained in the previous discussion

A vernacular settlement can be understood as building a house together, in the eyes of the public as an architect who doubles as a worker. So the community group that built the place of residence gave birth to a village, located in the interior and more traditional, adaptive to local customs and culture. Established community groups tend to settle in hereditary areas so that the settlement is considered a place of birth.

The realization of settlements as dwellings with all the facilities is more determined in the process of formation than the dwelling products produced. Improving the quality of society in one community is always based on the quality of its carpentry technology and must implement an initiation process at every stage that is made aware of the community's traditions, for example before the activity begins "Kenduri" or Excitement is carried out as part of the tradition. Architecture is not only in the form of form but also in the form of social space, symbolic space, which reflects the space of creation and population in the form of architecture (Olive, 1997)

Implementation of the settlement development process is generally determined from generation to generation or based on agreements relating to the local orientation that can be trusted so that what is built will be similar even though not completely the same. The local orientation of the vernacular settlement explains three things: place, person and period (time) as their architectural form, therefore the local orientation of the settlement becomes the keyword. Thus vernacular settlements are also called local villages or local settlements because they can grow, develop, assimilate naturally and continue to grow today.

\section{Method}

Determination of qualitative methods with a phenomenological approach used in this study refers to the real conditions of the To Kaili people who only have a culture of speaking (oral culture) and the phenomenon of customary rules and customs that are not written so they need special methods/ways to extract information from them.

In gathering information, some instruments are used observation and interviews and observation instruments are intended to get a picture of the reality of the object so that the observation information is expected to describe the object under study properly. While the purpose of the interview instrument is to uncover what is behind the reality of the object. For this reason, qualitative research with phenomenology, in its analytical procedures and analysis results, yields findings that have high reliability based on three reductions known as ethical reduction, phenomenological reduction, and transcendental reduction. The process of ethical reduction is considered to explore information that gave birth to various themes, then the reduction of phenomenology is intended so that through these themes can be explored the concepts in it, as well as transcendental reduction, intended to find the essence of concepts that lead to the formation of initial theories (cannot be generalized). Transcendental reduction requires an internationalist (awareness) research process involved in the analysis process consisting of intentional/objective awareness Intends to direct information on intentional objects because intentional objects only appear when there is data (Data phyletic), so the intended function 
here connects data with objects. Such objectification is especially apparent for example in perception and other awareness activities such as in thinking and doubting.

- Intellectual/identification awareness Intends to direct a variety of data that arrives from various events and then to object objectification results. Recognition is much influenced by various aspects such as motivation, interests, involvement. This designation is necessary because if it does not exist, then there is no identical object. This just causes "sensation".

- Correlation/awareness, awareness Intends that every view of identical objects has a relationship, for example, how the front points to the side. Connections of objects provide an opportunity for the subject to experience another time. This means that prospects will always be overshadowed by identical objects that have been seen from the beginning.

- Intentional/institutional awareness intended that activities that function constitute intentional objects so that intentional objects are not viewed as something that already exists for intentional activities, but is created by intentional activities. In other words, intentional objects come from "deposits" intentional activities

\section{Results}

\subsection{Findings}

This research journey found several themes that emerged, namely: 1) Theme related to the role of local wisdom, 2) The role of planning strategies in developing sustainable settlements, 3 ) the process of metamorphosis of settlements

\subsubsection{Local Wisdom}

The history of the development of the ToKaili community began in $2000 \mathrm{BC}$ to $8000 \mathrm{BC}$ which continues to evolve until it becomes a harmonious development of life, it is indicated by finding some evidence of relics in the form of menhir stones in several areas in Central Sulawesi. The existence of the Menhir is evidence that a high-cultural settlement has been formed which is heavily influenced by the inclusion of immigrants who come from many migrant groups to the ToKaili land. The presence of immigrants influences changes in their behavior. Menhir relics that were thought to be between $2000 \mathrm{BC}$ to $8000 \mathrm{BC}$ years ago, the arrival of these immigrants in the land of Kaili brought stone culture, much evidence of relics such as megalithic statues erected in several places shows the progress of ToKaili at that time. Migration to Tanah Kaili by community groups affects cultural acculturation between indigenous peoples and migrants, giving birth to a culture that can last a long time will continue to exist, while other cultures can not be extinct. The result of cultural acculturation gave birth to various customary provisions which are part of the ToKaili local wisdom which is their legacy. This cultural acculturation cannot happen by itself but with a series of events that give birth to culture. After experiencing acculturation from time to time, acculturation is formed as part of the process of forming local wisdom that can be accepted by the community and recognized as part of their culture. One culture that was formed along with acculturation is the Culture of War between the tribes of the Malay), which has an impact on the dichotomy of community groups, namely: people who can be called madika and people who are not able to be called watau or slaves

The formation of community groups due to the culture of war between tribal groups in the ToKaili community caused some groups within the tribe to experience extinction because they could not defend themselves and also caused some of them to form small ToKaili groups that lived separately and closed. One of the tribes that can still be found as a tribal group that still maintains an exclusive (closed) condition is the Wana tribe who live in several places on several hills in Central Sulawesi. This group formed the Kaili tribe group who settled in the valleys around the mountainous areas until the valleys near the coast became an open group.

Awareness of the negative influence caused by the war between groups pushed ToKaili to leave that culture. This effort was also initiated by the emergence of a wise and highly knowledgeable person called Tadulako (a wise and enlightened person) who was a figure of character and introduced a culture of living together and protecting each other between groups. The culture of mutual protection gives birth to agreed traditional rules and is part of local wisdom that always tries to find out how to live in harmony between groups and between one group or another group or ethnic group.

Harmonious life post-war culture between groups (Pengayuan) can be achieved by promoting the relationship between fellow human beings (Hintuvu), the relationship between humans and the environment (Katuva), and the relationship between humans and the natural ruler (Pehakovia), between the three relationships, become important aspects that are described as the philosophy of life of ToKaili. The relationship patterns of these three aspects are described in the form of an image below. 


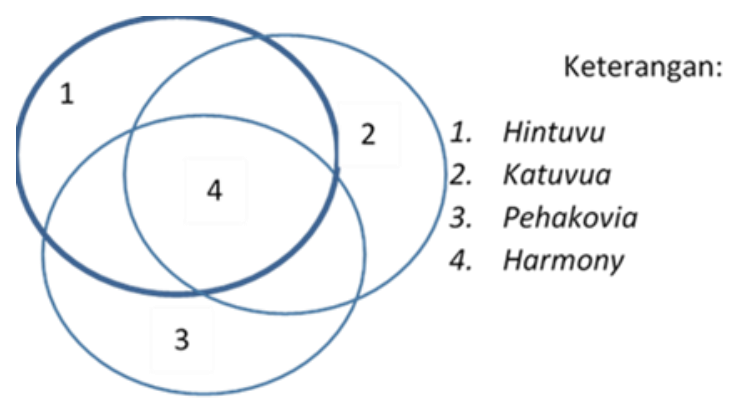

Figure 1. Principles of To Kaili harmonious live

Figure 1 above shows the phenomenon of the live interaction of ToKaili to achieve harmony in life in the world. 3 basic principles become the foundation in creating a harmonious life between humans with humans, humans and nature, and humans with the natural authorities. The three principles are the source of customary rules that guide To Kaili to live in a group or community life. These three principles are related to efforts to achieve harmony in life.

The first principle is Hintuvu or the relationship between human beings, the second Katuvua or human relationship with nature, the third Pehakovia or the human relationship with the ruler of nature. The three principles above illustrate that harmony cannot be achieved optimally without applying the three principles and making the three interact

\subsubsection{Strategy of Planning and Sustainable Settlement Development}

Based on observations and analysis of conditions illustrates that in planning and designing the life of ToKaili, the main strategy used is to actualize three principles, namely: Hintuvu, Katuvua, and Pehakovia explained earlier in the discussion on customary rules and becoming the ToKaili Guide towards achieving harmonious life. in this world.

These three principles are interpreted as the entire life system of ToKaili. And if it is sounded, it is found a sub of each system which is an elaboration of each basic principle and then it is translated into a system that is used to build customary rules. Each system (Hintuvu) describes the implementation of a part consisting of Humans, networks, and residential structures. While Katuvua revealed the interaction of the three 3 parts of the microcosm realm, namely: the Above Realm, the Middle Realm, and the Lower Reality, while the Pehakovia elaboration shows the position of the natural ruler in human life, which is then translated into customary government and leadership. Figure 2 shows how the basic principles of internal interaction in the life of To Kaili.

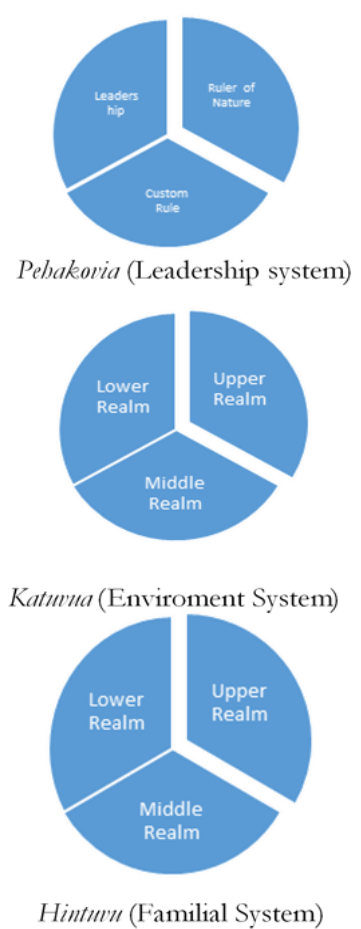

Figure 2. Sub-System of harmonious live system 
Further explanation of Figure 2 explains how the ToKaili strategy in the effort to find harmony is built through a balance between the system and sub-systems as well as the supporting parts that drive the birth of a great system called the harmonious system. Settlement structure as a place for ToKaili in developing internal and external networks, making humans the subject of planning to form a family system (kinship). This system cannot achieve harmony if it is not supported by other subsystems such as environmental subsystems related to the natural management sub-system and leadership related to housing structure management.

A harmonious planning strategy in the ToKaili community requires synergy between the entire system and every part of it, each element in the ToKaili life system is a pillar of mutual support in the effort to build a sustainable life in the ToKaili community to achieve harmony.

So that the three basic principles can synergize, the relations of the three pillars must be balanced and if there is an imbalance that occurs in the system will result in a relationship that is not aligned. Therefore, one sub-system's role concerning other sub-systems becomes very important to protect each other to maintain stability in the life of To Kaili, and if an interaction between pillars is ignored into Kaili's belief as something that leads to a sign of disaster.

To maintain relationships remain harmonious in the lives of ToKaili, customary rules are needed as a director and play an important role in managing the mechanism of the system working in the Kaili community. Thus customary rules become regulators in ToKaili. Habits and also has a role in planning and designing the needs of ToKaili's life. Several customary rules have an important role in managing the behavior of life in the ToKaili community, including rules about building leadership, kinship environment, and cosmology. The rules of the implementation are outlined in the decision making procedure. Which is explained in the picture below?

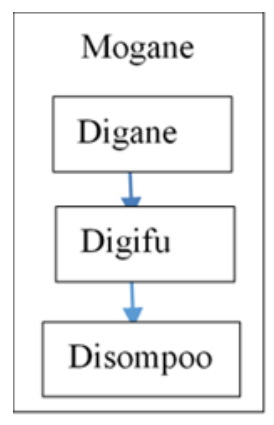

Figure 3. Application of custom rule process

Figure 3 shows the process of implementing decision making in every effort to maintain the balance of life order in ToKaili. Mogane is a decision-making system run by Totua. Mogane or decision making has stages consisting of 3 stages as Digane is the delivery or act that is deemed to violate customary rules to Totua which is then addressed by holding an adat council meeting (Molibu). Which discusses the problem that needs to be agreed upon rules to be applied on the behavior of tribal people who violate customary rules.

Digane jigs can be used to determine the strategies used to plan and design residential developments for residents.

the next process is the Digifu process which is a process of collective decision making by Totua in the council after being formulated in the digane process, while the Disompo process is an execution of the Totua agreement if it is a form of violation committed by a group or individual, then digifu is a form of compliance for violators of the rules for serving a sentence to redeem himself. whereas if it is an effort to build a broader settlement, then digifu is an agreement to develop together with the principle of one heart and join hands or cooperation.

The decision that was agreed upon in the Mogane forum was a decision that had to be made and continued with the increasing familiarity of the community members in living together.

Customary leadership in the ToKaili community has established a structure that starts from the family leadership stage to the settlement leadership stage. In the Family stage, known as ToTua (parents), parents are responsible for educating and teaching their children so they can carry out their duties in following customary rules in their tribe so that when children grow and have a family but cannot live independently parents cannot allow living independently in a group meaning that they have to be at the parents' house, and parents are not yet obliged to build houses for their families,

So that the child's family is still the responsibility of parents, and there is rarely a family in the family because the desired family is seen as unable to live independently. This culture is still firmly held from generation to generation until now, observations show that there are still several families of ToKaili's parents in his house with several families so that one house can consist of several heads of families. For families whose children's families can stand alone, parents' families 
must provide a suitable home near them.

In Kaili's customary provisions, after marriage, boys must follow his wife or family, while the wife cannot leave the house without her parents so that married men will be the responsibility of the female family.

This phenomenon gave birth to the theme of traditional leadership which showed the role of women in the life of To Kaili, which is very important in determining inheritance rights in Tokaili society. When there is a marriage the dowry given by the men is in the form of several pets that are owned.

When all their children can live independently, the obligation of parents to build a house for every child who has a family then their home group will form a small scale settlement (Boya) consisting of several close families, and they will elect the Boya leader through the mogane process The result, the oldest in some families, became Totua. This happens when the parents of these families who always lead them appear to be unable to lead them because of their age or death. With this, they have the task of carrying out Mogane to select a new Elder for a new family group in their new Boya, but each family is still led by an independent family head who respects the Elder.

The head of the settlement, the head of the larger settlement (Ngata), if formed by a federation of several families forming a larger village led by several ToTua as representatives of their village. The leadership structure in Ngata consists of several ToTua (Boya representatives), Maradika and Speaker. Maradika is the same as a government official in a settlement and the Speaker is the same as a spokesperson and interpreter who submits the formulation of the results of customary rules in the council that will be executed by Maradika.

the hierarchy of settlements in the multi of Boya, Ngata and Ngata Bete is the stage of development of settlements in the ToKaili community, Ngata Bete is the highest form of a settlement known as a large settlement, and has a government system in it which is comprehensively structured as follows: Jagugu as a spiritual leader and being an advisor Tina Ngata and Jagugu are people who have spiritual skills and also have judicial rights, as explained, Jaggu has the right to impose sanctions on individuals or groups who have violated customary rules through conferences in councils with old To, while Tina Ngata is leaders whose decisions cannot be contested because Tina ngata is a woman who controls the village land occupied by customary rules, Matadika is the ruler assigned to regulate community life patterns and Pabicaran who is a counselor whose job is to deliver the results of decisions taken at the moment of molibu.

Every leader in the effort to uphold customary rules (Vaya) or plans to develop the environment must follow the customary rules set out in the Vaya that are by the basic principles that form the philosophical basis for drafting customary rules.as described previously.

\subsubsection{Settlement Metamorphose}

The culture of living starts from the culture of living which gives birth to the concept of home and village. Houses in ToKaili's understanding have different names depending on where they live, houses located in valleys from high hills like Lore are known as Tambi, and houses located in valleys surrounded by hills like in Kulawi are known as Sou, while houses are placed in a valley near the coast known as Banua.

The house at the beginning of its development began with the need to protect itself from the weather or climate such as rain and sunburn which made ToKaili make a shelter known as Torowau. Such a house is a form of a pile of leaves placed on two wooden poles that rest on four pillars and make a space underneath as a sanctuary. Further development of this pattern has increased by developments in the needs of community life at that time. Improved housing patterns, not only become a place of refuge but also a place to rest together known as Bamaru Ncamali.

In the next stage, nomadic culture was upgraded to a sedentary culture because it was influenced by the arrival of outside migrants in Tanah Kaili. The migrants who came to introduce the form of a house as a place of residence known as Bolawo and Bolanoa, Bolawo forms it consists of a pile of wood that is linked and tied to rattan so that it supports the floor and then makes a frame that functions as a rooftop building, such houses are only given to their leader (Madika).

Bolana is made using small logs tied to the shape of a house and given to the working class (Watau).

House forms as explained before.

The forms of houses continue to develop when they have settled permanently. Furthermore, the house has a different name and shape according to where it was built.

The mountain house is known as Tambi, the house built in the lower mountainous region is known as the Sou and the house built in the coastal area known as Banua.

The arrival of the Bugis and Mandar tribes gave influence on the shape of the house, so they introduced the stilt house (Rumah Panggung) known as Pabuhu Hampua and Pabuhu Dola. Pabuhu Hampua is a house on stilts that uses raw, whole woodblocks, the lower end of the wood is planted firmly to the earth, and this house uses durable wood that is waterproof 
such as ironwood or ebony. While the Pabuhu Dola is the same house as the Pabuhu empty, but it is influenced by technology so that the wood that has been processed into rectangular beams. This change process is the metamorphosis phase of all ToKaili houses. Unfortunately, the results of extracting information, there is no information about the timely development because the culture of writing does not exist in the ToKaili Culture.

The form of the metamorphosis of the ToKaili settlement can be observed through special orders, ranging from houses to large villages (Ngata Bete). Every spatial planning for To Kaili requires activities that are always based on cosmological rules that govern space. In Adat rules, To Kaili has a sacred space, a semi-sacred space, and a forbidden room. This is based on its value, for example, the sacred space is a purified space because in the belief of ToKaili, space is believed to be the place where their ancestors lived as on a mountain and the semi-sacred space called Oma is given to humans to carry out their life tasks while the forbidden space is a river and messy water. ToKaili's belief considers that this place is the abode of evil spirits or their ancestors who were refused to join the top of the mountain or the upper realm because of their behavior when they lived because they always broke the rules.

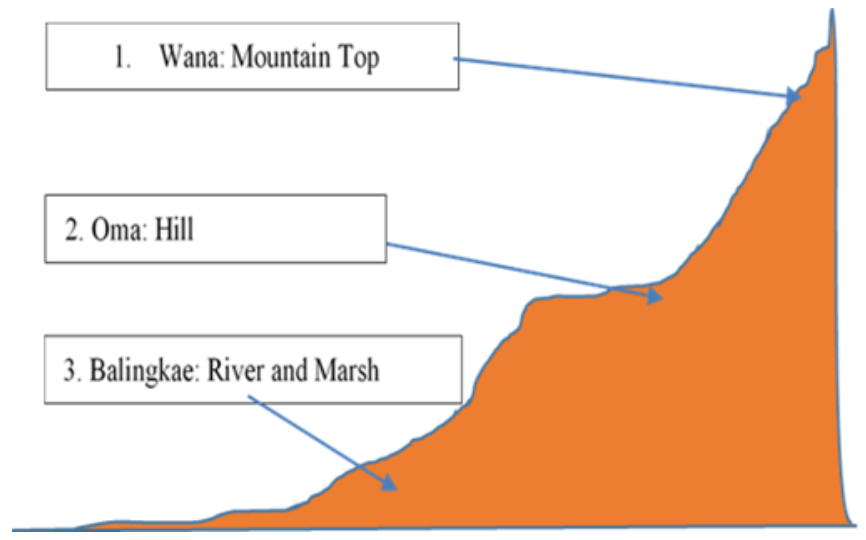

Figure 4. Nature Cosmology according to ToKaili Custom (zaenal, 2015)

Figure 4 Show cosmology perspective that implemented into the settlement, start from the house (micro-scale settlement) up to Ngata Bete (macro-scale settlement). Application of cosmology element in house and settlement manifested in space arrangement on small scale settlement up to great scale settlement, in sacred space form, human space, an unclean space. Sacred Space in the house is identified as a kitchen, human space identified as room surrounding the kitchen and unclean space identified as outdoor vicinity of house livestock bin. See picture 5a

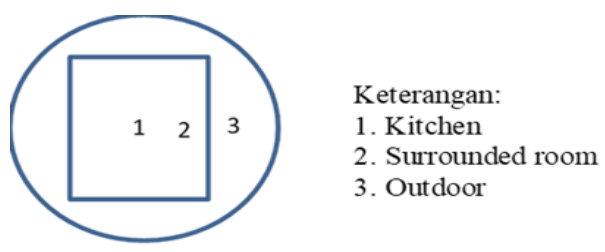

Figure 5a. House

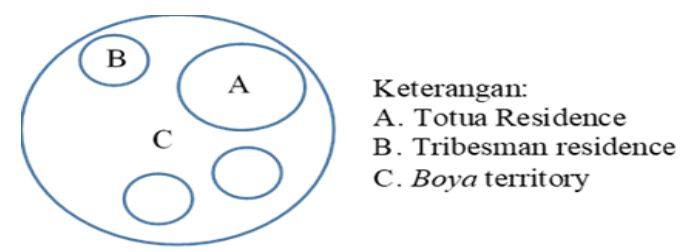

Figure 5b. Village (Boya) (zaenal, 2013)

So in settlement space arrangement there always three aspects in that the application differs depending on the scale of the planned settlement, on Boya scale, sacred space identified as Totua Residence and human space identified as tribesmen residence within Boya territory and unclean space identified as an unoccupied area of Boya territory confined by a ditch that acts as the border as explained in picture 5.b.

In Ngata and Ngata Bete, Sacred room identified as a landmark that its name varies depending on its location. For the highland area, for example, Lore has a sacred landmark named Duhunga that no longer exists. Middle land named Lobo still able to be found its replica in Kulawi and Toro, while in low land or valley like Palu identified as Baruga. Next is 
human space is a group of Boya that form Ngata. And unclean space is the vast edge of border territory and in a few areas functioned as a graveyard as it near to water source (River and lake). Please see picture 7.

Picture 6, middle scale settlement pattern (Ngata) (zaenal, 2013)

In the most complex and signifies that To Kaili already form a city with its complexity arrangement in great settlement (Ngata Bete). Ngata bete is a group of settlements that represent the human environment that owns sacred space in form of the central government also surrounded by farm and field as territory border that also has a water source that identifies as unclean space.

\section{Discussion}

Planning and designing residential spaces with local wisdom generally have a basic philosophy that is a reference, that is why the faithful philosophy of indigenous groups always exists but has a difference for each of the indigenous peoples or tribes in the world. Like the Kaili or ToKaili tribe has a basic philosophy which is the basis for the preparation of strategies in the design and planning of settlements that they create. The To Kaili community in creating a harmonious settlement through the application of the basic philosophy outlined in three main foundations namely Pehakovia, Hintuvu, and Katuvua, all three are used as basic principles in agreeing on customary rules adhered to the To Kaili community. The customary rules adopted are intended as a shield to maintain the balance and harmony of life between humans and the environment and humans with nature's rulers so that the To Kaili community and other groups who are part of their society can coexist with each other and with their environment can always avoid disaster.

Customary rules as an embodiment of a harmonious balance are used to fortify human behavior that is considered to be deviant because it violates the agreement that becomes customary rules, must receive a warning or punishment so that every human always tries to adjust to fellow humans and their natural environment, so obedience is expected to be an effort to lead to the application of the system holistic where the balance between one another in a system that is always demanded by customary rules, to achieve a harmonious balance requires the integrated interaction of all systems or achieving a balance that refers to the synergy between each system that makes the whole system. This explanation is identical to the opinion of the Hold and part principle by Jhonson PA (2000).

The three pillars that form the basic philosophy before formulating it into customary rules are first understood as beliefs about the existence of a natural cosmology that Tokaili believes to dictate ToKaili between the macro cosmos and the microcosmos, and each cosmology consists of the upper realm as their ancestral place is to reach heaven, the upper realm is identified as the top of a mountain or hilltop which becomes their high point of view around it when viewed from the macro cosmos, while in the micro concept the natural cosmos is at the top of the house. The middle world is identified as a valley that they believe to be a place to live and live (Pengataa) in the concept of macro cosmos while in the concept of microcosmos is identified with the body of the house where humans are active, the micro cosmological understanding of the realm is applied to the kitchen and the floor with Asira or elevated floor which functions as a bed. And nature is a region of rivers, lakes or swamps in understanding the macro cosmos, while in the concept of a microcosm is a pit that functions as a cage of livestock.

Nature is also identified as open space or unclean space so everything that comes from there must be cleaned first before being used properly. These principles are then used as the basis for formulating planning and design strategies customary rules relating to building social networks in communities and building ideal and harmonious settlements as a forum for interaction between people and with nature and the environment.

The implementation of customary rules on settlements is done in stages and planned and designed starting from small scale such as Boya, to medium scale (Ngata), and large scale such as Ngata bete. it is by the findings of Zaenal (2015). Implementation at various scales shows the balance at each stage becomes a benchmark in developing so that the development of settlements occurs when the existing settlements reach an optimal balance. The process of development is identical to and by Pareto's theory which says each stage has a balance point, as an optimal condition and if it is expected to develop even greater then it is known with an imbalance which then leads to continued equilibrium.

The form of balance and harmony at every level of planning and design of the physical environment in the To Kaili community is strongly influenced by the leadership of the indigenous peoples that are formed so that each level of settlement, customary rules and their application together with basic principles, makes customary rules as the main pillars of upholding harmony and becoming the basis for the application of Local Wisdom and also depends on how customary leaders implement customary rules through councils (Molibu). This view coincides with the view of Rapopt A (1963.1979.1977) about his understanding of Architecture, culture, and design. 


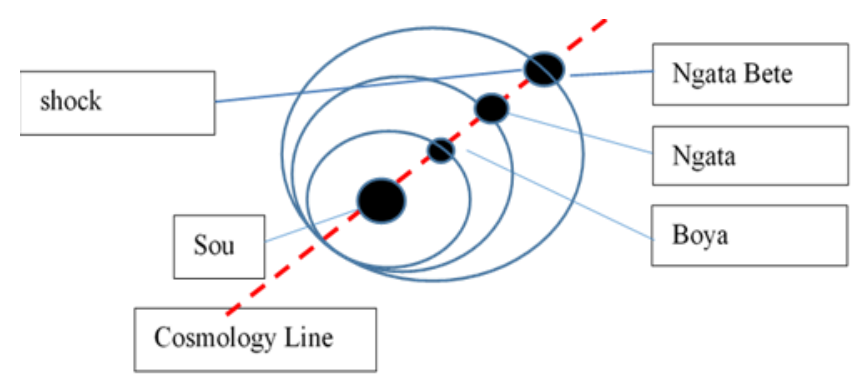

Figure 6. House structure and traditional ToKaili settlement

Figure 6 shows the implementation of a sustainable design plan giving birth to strategies that form a gradual settlement structure that starts from the house to the Sou and grows into a Boya, and becomes a Ngata.

each stage is an ideal and harmonious form. New equilibrium formed from the stages of settlement development such as Boya to Ngata Bete are stages that go beyond a long time. While Ngata Bete is the highest form of balance and harmony in the ToKaili settlement. If seen from the development of Ngata Bête, the birth of NgataBete is a process of cultural acculturation between the culture of To Kaili and the culture of migrants which influences the birth of a more complex form of Ngata Bête development consisting of Patanggota and Pitungngota.

Ngata bete with Patanggota customary rules dividing four regions based on skills in their citizens, while Pitungngota culture develops areas based on the development of knowledge and technology owned so that Patanggota is the division of territories to develop certain areas to focus on certain skills such as power territories, mystical areas (responsible against defense) treatment areas, and agricultural areas. While Pitungngota has a much broader regional division such as the merchant area, craftsman area, and forecast area.

\section{Acknowledgments}

Local wisdom is owned by almost all community groups or tribes and is part of the culture of the community which is handed down from generations of generation. Local wisdom is always experiencing development so that there is local wisdom that can survive until now with various adjustments to the evolving environmental conditions, and local wisdom is a guideline for the community including ToKaili. In planning and designing the fulfillment of the necessities of life such as clothing, food, and shelter the model and shape are adapted to the habits of the community as set out in the community's life principles. ToKaili through the Mogane mechanism. In Customary rules are then translated into rules relating to humans and the natural environment.

The customary rules that are formed are one of the planning and design strategies that lead the To Kaili community to agree on the procedures and behavioral procedures that become the director of planning and design of living and socializing in the ToKaili community. Thus to Kaili has a belief that appreciates the preservation of nature with existing rules. And strategies that make the rules on the management and protection of nature used to preserve them. while strategies that use rules that refer to social models and trust in natural authorities strengthen the application of adat rules. The implementation of customary rules in the community is carried out through the Mogane process with all its designs applied by To Tua or his cultural leaders by always considering balance and harmony, and always keeping the community from violating, and if violations occur have already been sanctioned by giving sanctions to violators of customary rules that destroy nature or makes a distortion of society. Mogane is also used to assess the skills of cultural leaders about how they control their people not to break the rules and also to encourage the people of To Kaili to develop people's lives by rewarding and enhancing them to become public figures because they served to the Kaili community.

The golden period of the application of customary rules in regulating and managing the lives of the people around To Kaili ended when Indonesia declared its independence, this was due to government policies for uniform management of community life such as changing government management from the village scale. Changing adat rules into law positively influences efforts to protect central authority. The application of customary rules and people's obedience to them faded to the point of extinction. With this, customary rules only apply as part of the culture displayed during the To Kaili Event such as weddings, birth events, events of death and there are no loggers that apply to plan and design in the To Kaili way of life.

\section{References}

Amos, R. (1977). Human Aspect of Urban Form. New York: Pergarnon.

Dalsgaard, P. (2014). Pragmatism and Design Thinking. International Journal of design, 8(1). 
Doxiadis, C. A. (1971). Ekistics, An Introduction to The Science of Human Settlements, printed in Great Britain on Beaublade Cartridge Paper by Anchor Press.

Healey, P. (2009). The pragmatic tradition in planning thought. Journal of planning education and research, 28(3), 277-292. https://doi.org/10.1177/0739456X08325175

Holden, M. (2008). The tough minded and the tender minded: A pragmatic turn for sustainable development planning and policy. Planning Theory \& Practice, 9(4), 475-496. https://doi.org/10.1080/14649350802481371

Johnson, P. A. (1994). The Theory of Architecture: Concepts Themes \& Practices. John Wiley \& Sons.

Keiser, M. B. (1978). Architecture Environmental aspects. Macmillan Publishing Co.Inc. New York

Kudern, W. (1944). Ethnographical Studies in Celebes, Results of the Author's Expedition to Celebes 1917-20, I Game In Dance in Celebes, Printed In Sweden, Goteborg, Erlander Boktrvokert Aktebolag.

Kudern, W. (1944). Ethnogrphiral Studies in Celebes, Results of the Author's Expedition to Celebes 1917-20, VI Art In Celebes, Printed In Sweden, Goteborg, Erlander Boktrvokert Aktebolag.

Kudren, W. (1940). Structures and settlements in central Celebes, London, (1917 - 1920).

Kudren, W. (1940). Structures and settlements in central Celebes, London, (1917 - 1920).

Mattulada. (1988). Andi, To Kaili, penerbit Untad Perss.

Mete turan. (1990). Vernacular Architecture. SocialAspects, publishing By Avebury. Aldershot, HansGUII3HP> England.

Oliver, P. (1987). Dwellings: the house across the world. Phaidon.

Rapoport, A. (1969). House form and Cultua. London-University College: New Delhi: Prentice-hall of India Private Ltd, 73.

Rapoport, A. (1973). Some perspective on Human use and organization of space, in the thirty-three Paper in Environmental Behavior Research, the Urban International Press, New York.

Zaenal. (2013). Permukiman dan arsitektur Rumah Tradisional To Behoa di Sulawesi Tengah, suatu pengkajian perilaku, Prositding Seminar Nasional Space\#1, Penataan Ruang berkeaarifan Lokal dalam pembangunan berkelanjutan 2013. Isbn 978692-14304-0-9 tahun 2013.

Zaenal. (2013). Pola Bermukim to Kaili Di Sulawesi Tengah, Prossiding Seminar Nasional, Reinterpretasi Identitas Arsitektur Nusantara. Isbn 978-602-7776-68-5, tahun 2013.

Zaenal. (2014). Hintuvu consept on Settlementon Kaili in Centra Sulawesi, Proceeding, The 15 th International conference on SustainebleEnvironmental Architecture. HasanuddinUniversity Facultas og Engineering. Isbn 978-602-71663-01 New Campus. November14-15 2014.

Zaenal. (2015). Hirarki dan keterhubungan Sou, Boya, Ngata, Ngata bete pada pemukiman Masyatakat To Kaili. Disertasi S3 Arsitektur, Ugm, 2015.

\section{Copyrights}

Copyright for this article is retained by the author(s), with first publication rights granted to the journal.

This is an open-access article distributed under the terms and conditions of the Creative Commons Attribution license (http://creativecommons.org/licenses/by/4.0/). 